\title{
The History of Planning for Kowloon City
}

\author{
*Lawrence W.C. Lai \\ ** Mark Hansley Chua \\ *Professor \\ Ronald Coase Centre for Property Rights Research, \\ Department of Real Estate \& Construction \\ University of Hong Kong \\ Registered Professional Planner, F.R.I.C.S., M.R.A.P.I. \\ wclai@hku.hk \\ ** Doctoral candidate \\ Department of Real Estate \& Construction \\ University of Hong Kong \\ mhansley.chua@gmail.com \\ mhychua@hku.hk
}




\section{The History of Planning for Kowloon City}

Lawrence W.C. Lai and Mark H. Chua

University of Hong Kong

5 March 2017

Keywords

Kowloon City, city of darkness, town plans, history of planning

\section{Abstract}

This short paper identifies from archival and published materials plans for a place called Kowloon City which had an Imperial Chinese military purpose and is now a public park (officially called "Kowloon Walled City Park") after a long period of dispute over its jurisdiction. These plans were mostly produced by the colonial Hong Kong government who made the first planned attempt to clear the place of Chinese residents for a public garden in the 1930s but this garden could only be built after the 1984 Sino-British Joint Declaration. They testified to the fact that the City has always been planned.

\section{Introduction}

The disclosure of formerly secret and confidential colonial Hong Kong government documents to the public has stimulated research on the mapping and planning of use of a famous place in Hong Kong called "Kowloon City" (hereafter referred to as the City), as can be found in the works of Lai et al. (2016) and Lai $(2015,2016)$. This place, called a "city" in both Chinese and English, was a source of embarrassment during colonial Hong Kong days, a popular imaging of the City by local people as a "place none of the three parties (Britain, China, and Hong Kong)

${ }^{1}$ Before the 1960s, all colonial government correspondence and maps referred to the KWC as "Kowloon City". However, it was known as "Kowloon Walled City" in official documents. 
governed" (in other words, a place under anarchy)., The governmentappointed Hong Kong Tourism Board (2017) depicts it as a place "remembered today as a haven of crime and debauchery," while overseas authors have deemed it a "City of Darkness" (Popham 1993, Girard, Lambot and Goddard 1999, Carney 2013). Both interpretations have fostered a distorted view that there was no government or planning for the City.

In the tradition of planning history inquiry (Bristow 1984; Home 1997) and the narrative of a "history of planning" in town planning practice, this paper traces eight phases of planning for the City based on archival materials unavailable to or not recognised by earlier influential works on the subject as a special place (Miners 1982; Sinn 1987) or as part of wider planning (Bristow 1984). In addition to those kept at the Hong Kong Public Records Office (PRO) and filed under "HKRS", a series of administrative and statutory town plans that covered the City were also examined. The former, which bound all government departments, were only made open for public inspection under the administration of the last Governor, Christopher Francis Patten, Baron Patten of Barnes.

The first phase was planning by the Imperial Chinese Government using the City as a frontier fort to watch the British Crown Colony of Hong Kong, which initially consisted only of Hong Kong Island plus six islets totaling $72 \mathrm{sq}$. km. To this was added the tip of Kowloon Peninsula (8.4 sq. km.) in 1860 and finally the New Territories (919.45 sq.km.) where it was located, ${ }^{2}$ in 1898 . The second was the colonial government's 1933 prewar plans for part of it to be a walled garden ${ }^{3}$ and the third was a Republican Chinese official's post-World War II outline plan to assert Kuomintang (KMT)/Nationalist jurisdiction over the City, by which time

\footnotetext{
${ }^{2}$ A strip of the New Territories to the south of Kowloon Range extending from Lai Chi Kok in the west to Lei Yu Mun in the east was called "New Kowloon". The City is in New Kowloon.
}

${ }^{3}$ The CO129/544/14 (1933) file was disclosed to the public in 1984. 
its granite walls had been stripped by the occupying Japanese for the construction of an expanded Kai Tak Airport. The fourth was the socalled Abercrombie Report of 1948 (Abercrombie 1948) and the fifth was the colonial government's post-war efforts to convert it, after all its walls had been demolished by the Japanese, into a public housing estate. The sixth was a series of "administrative" Outline Development Plans (ODPs) that zoned the City as "Commercial/Residential". The seventh was a series of statutory layout and "Outline Zoning Plans" (OZPs) that designated the City a commercial/residential zone. The eighth and final one was a plan to convert the City from a high-rise slum into a park, as per the Sino-British Joint Declaration of 1984 to hand Hong Kong over to Communist China in 1997.

This survey of plans, based on an analysis of Chinese and English archival materials deposited at the PRO and Planning Department (originally Town Planning Office), is timely, as the popular image of the City, represented as a "Walled City," is that it was anarchistic in the absence of any government planning. While not all of the planning efforts involved blueprints or maps, all plans have definitive, rather than spontaneous, purposes even though they seldom fully achieve their aims if at all.

Before a narrative of Hong Kong's planning history, there is a need to explain the sources of information used in this paper in relation to some basic relevant constitutional matters. Hong Kong, as a British Crown Colony, was administered by a Governor appointed by the Crown and who sought advice until 1854 from the War and Colonial Office (later the Colonial Office) until 1966, when it was renamed the Commonwealth Office. Since 1968, it has been known as the Foreign \& Commonwealth Office (FCO). Relevant archival correspondence between the colonial government and the War and Colonial Office from 1842 to 1951 for this study was filed under CO129, the index (complied by Dr. Elizabeth Sinn) 
and papers of which could be inspected, respectively, online ${ }^{4}$ and at the Hong Kong University Main Library.

The Governor had complete autonomy to govern Hong Kong under the Hong Kong Letters Patent and Royal Instructions. (Miners 1981) The entire Colony was carved out from the southern tip of Imperial China's San On (Xian) County in three stages under international treaties: 1) Hong Kong Island in 1842 under the Treaty of Nanking; 2) Kowloon Peninsula in 1860 under the Treaty of Tientsin; and 3) the New Territories in 1898 under the Convention of Peking. ${ }^{5}$ Kowloon City was acquired under the third annexation.

Figure 1 shows the location of Kowloon City in relation to various places in colonial Hong Kong and its wider regional context. ${ }^{6}$ Figure 7 shows the key public roads that were built near the City and referred to in this paper.

For a history of planning of Hong Kong until the 1984 "Sino-British Joint Declaration Concerning the Future of Hong Kong," the work of Bristow (1984) is an excellent reference. The Governor in Council was the top local planning body, but in 1939, provisions were made by a Town Planning Ordinance for the establishment of an appointed Town Planning Board (TPB) to oversee the "existing and potential urban areas" in all of Hong Kong. The TPB could only start functioning after a Town Planning Office (TPO) was created in 1947 with the Public Works

${ }^{4}$ http://sunzi.lib.hku.hk/co129/.

${ }^{5}$ See Appendix IV, A Selection of Constitutional Documents, Conventions and Treaties, Historical Laws of Hong Kong Online. http://oelawhk.lib.hku.hk/items/show/3631.

${ }^{6}$ The map was a 1927 map $(\mathrm{H} 25)$ drawn to a scale of 1:126720 produced by the Public Works Department of Hong Kong Government. The insert is from a 1:100,000 1957 map (H26) produced by the same department. 
Department as its supporting apparatus. The TPO became the Planning Department in 1990.

For both statutory planning (by way of OZPs and other categories of plans produced under the Town Planning Ordinance) and administrative planning (through such means as Crown Leases, Layout Plans, and ODPs), there has been no devolution into any district council, as Hong Kong has no history of local governments, as in the case of New South Wales.

\section{Figure 1: Location of Kowloon City}

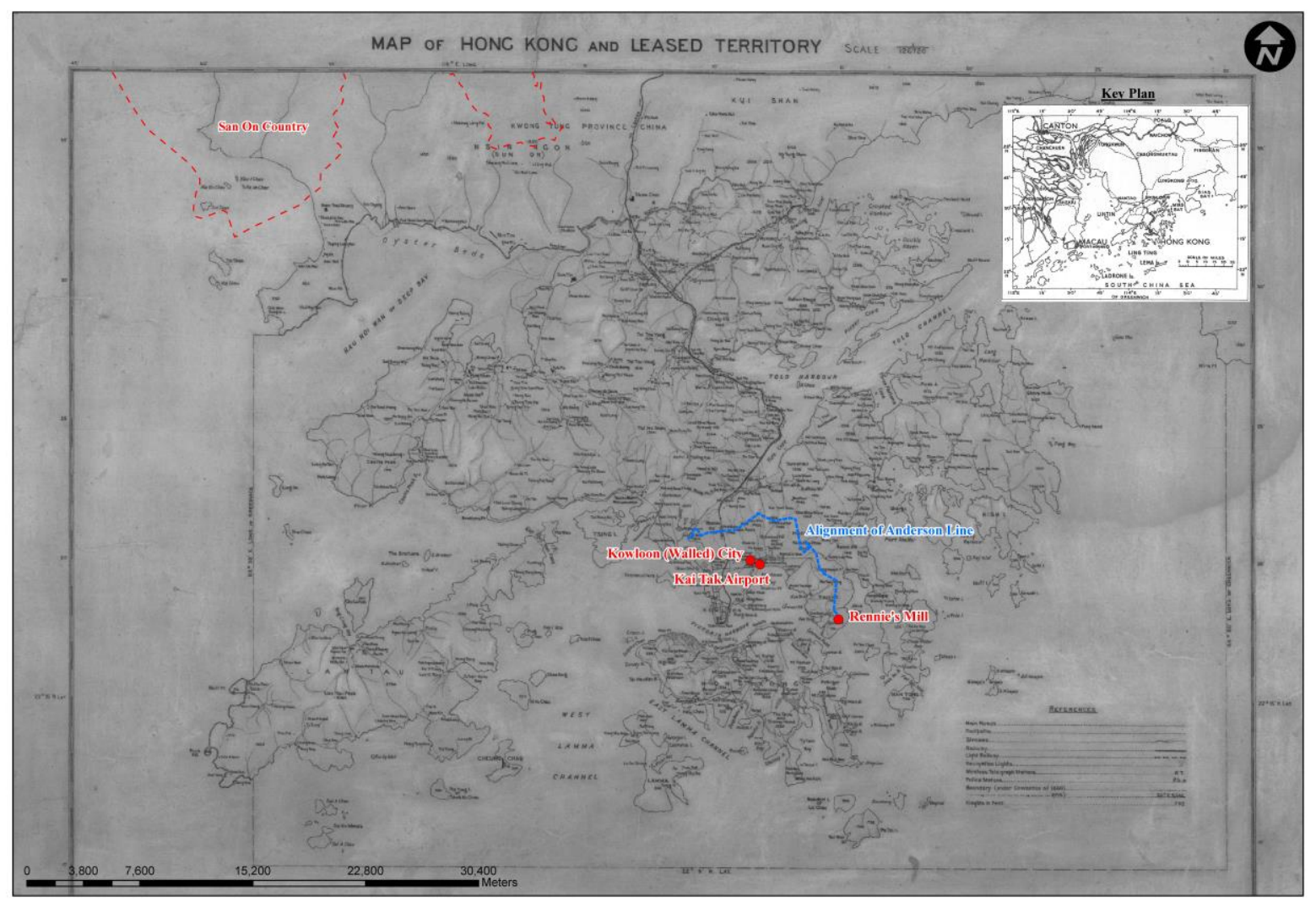

Military Planning by the Imperial Chinese Government: a Coastal Fort with a Pier 
During the Sung Dynasty (960-1279), Kowloon, then called "Kun Fook" (Xiao 1987), was famous for its salt fields (under a government monopoly) administered from a stockade of the same name that was purportedly located where the City stood. Nevertheless, the site of the City first appeared as an official place name in Imperial Chinese records as a beacon tower in 1668 and then a marine base (九龍汛) in 1682 during the reign of Ching (Qing) Emperor Kang Xi (Jin 1688). The base was further upgraded to a fort in 1810 well before the First Opium War. (Xiao 1987)

After the defeat of China in the First Opium War in 1843, the City was planned and developed as a frontier post to protect San On County against incursion by British forces based on Hong Kong Island (Xiao 1987). By 1847, a seven-meter-high stone wall was built to strengthen the City's defence as a fort. A lower crab pincer-like wall was built on a knoll to the north of the main City wall. In the City were a Yamen (magistracy) and barracks.

On 26 June 1858, Britain acquired from San On County the tip of Kowloon Peninsula under the "Convention of Peace and Friendship between Great Britain and China," which settled the Second Opium War. The international boundary between British Kowloon and China came within less than a kilometer from the City (i.e., it became an important border fort for China).

The significance of this fort to China was manifested in the agreement for the "Extension of Hong Kong Territory," signed in Peking on 9 June 1898, which "leased" the New Territories for 99 years until 1997 to Britain to better protect Hong Kong from potential European enemies, especially in the wake of the Franco-Russian alliance and a newlyaggressive Japan after the First Sino-Japanese War of 1894-18957. The

\footnotetext{
${ }^{7}$ This period in international politics was known as the "Scramble for Concessions" in China.
} 
agreement expressly provided that "the City of Kowloon the Chinese officials now stationed there shall continue to exercise jurisdiction except so far as may be inconsistent with the military requirements for the defence of Hong Kong." Furthermore, the pier adjacent to the fort allowed free entry and exit for the officials and residents of the City. The border between Chinese territory and the land leased by the Crown is marked on the map attached to the agreement.

This phase of planning was implemented by China and a better-informed imagery of the true shape of the City with all its stone walls could be obtained from a survey map (simplified in Figure 2$)^{8}$ and photos taken in 1898 (See Figures 3 and 4) ${ }^{9}$

\footnotetext{
${ }^{8}$ This figure was based on a 1905 District Survey Sheet No.4 produced by the Hong Kong Government.

${ }^{9}$ Source: Information Services Department of the Hong Kong Special Administrative Region Government.
} 
Figure 2: A survey plan for the stone walls of Kowloon City

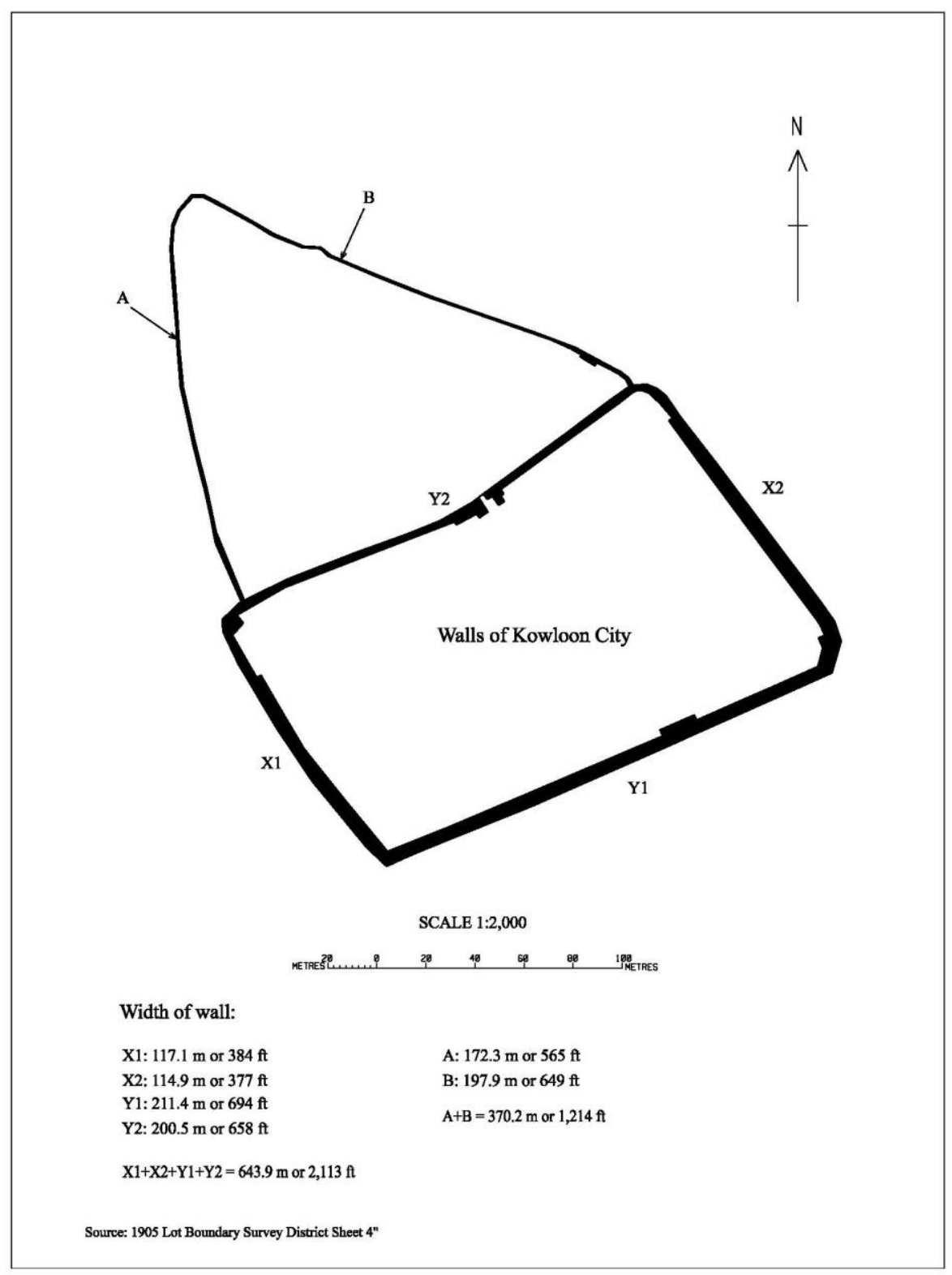


Manuscript for Planning Perspective

\section{Figure 3: A 1898 photo of Kowloon City}

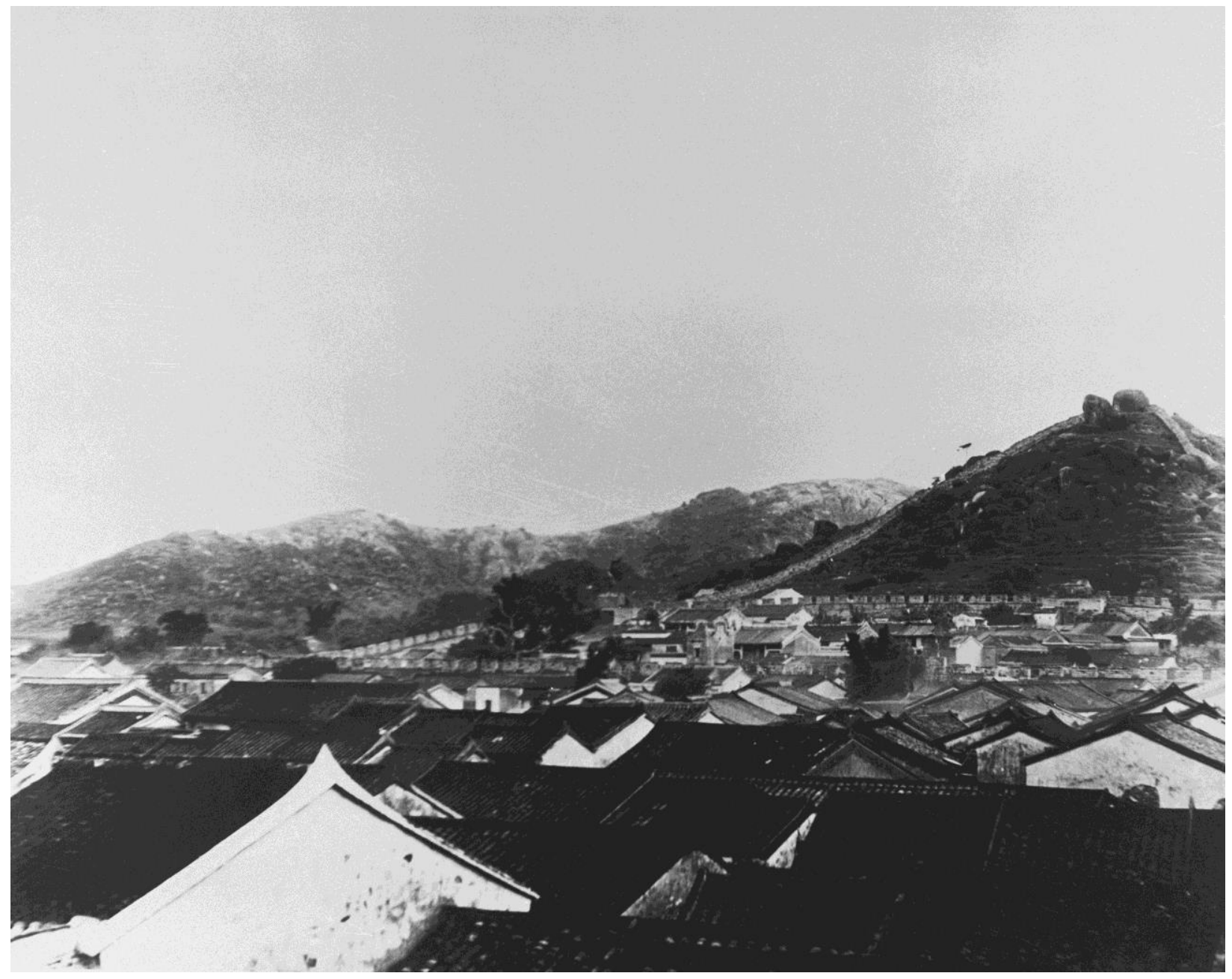




\section{Figure 4: A 1898 photo of Kowloon Pier}

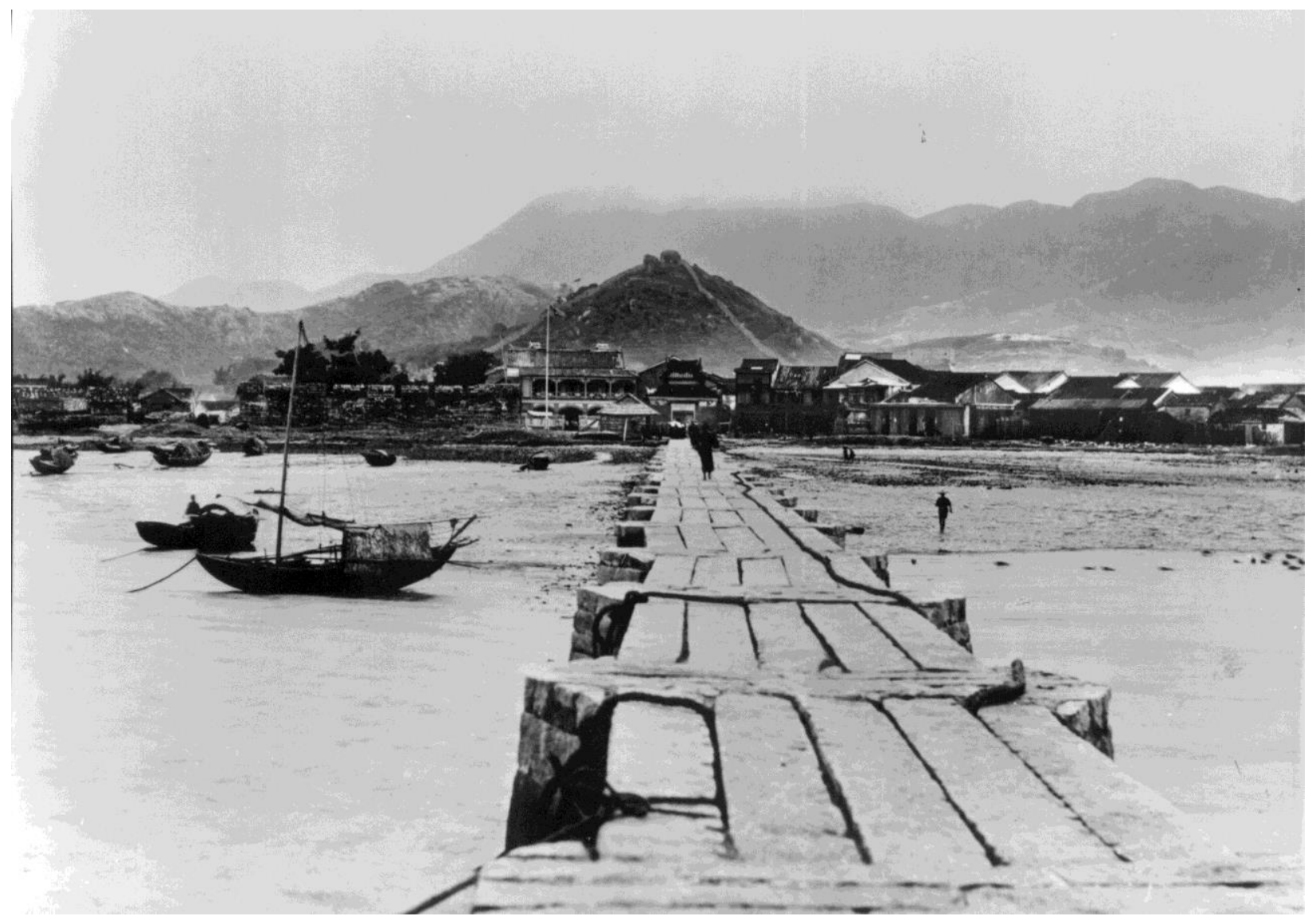

Development Planning by the Colonial Hong Kong Government: a Walled Garden

The leasing of the New Territories in 1898 from China for 99 years opened a new chapter in the planning for Kowloon City. The almost immediate expulsion of Chinese officials from the City sowed the seeds for future international disputes over the City's jurisdiction.

The fall of the Manchu (Qing) dynasty (1644-1912) and the rise of the Republic of China in $1912^{10}$, which stressed nationalism as a national

${ }^{10}$ The fall of the Manchu empire could be dated to the 10 October 1911 Revolution, which led to the declaration of "autonomy" by China's coastal provinces from 
policy ${ }^{11}$ right from the start, concerned the British because the Nationalist Government declared all treaties that ceded Chinese land to foreign powers as "unequal" and, hence, had to be revoked. One of the British responses with the modern Republican Chinese Army in mind was the construction of a series of blockhouses - the "Anderson Line"12 across the Kowloon Range from Devil's Peak in the East to Kowloon Reservoir in the west (Weir 2012). Eventually, the Chinese military threat lessened, as "warlords" fought each other, as well as the rising KMT Party, for control of China, before the invasion of Manchuria by Japan in 1931.

During the 1930s, with Japan looming as a far greater threat than China, the colonial government proceeded to buy out all leases in the City with a view to turning it into a public garden. A plan found in Colonial Office files $^{13}$ shows the walls of the City being circled by an open space reserve. The Chinese Government was informed, if not consulted, and it apparently did not object to this plan.

The buyout process was smooth, but the implementation of this park plan was frustrated by the outbreak of the Pacific War on 8 December 1941, when Japanese forces invaded and occupied Hong Kong from Christmas 1941 to 29 August 1945, when a British Fleet under Admiral Cecil Harcourt's arrived in Hong Kong and resumed British administration.

Peking, although the Emperor Puyi officially abdicated in January 1912 . He remained the emperor of the palace (the Forbidden City), but was later dethroned and driven out of the palace by a warlord.

${ }^{11}$ The perennial nationalist desire was to retake all territorial concessions and colonies ceded to the European powers by the Manchu Empire. This desire was fully fulfilled by the Communist regime.

${ }^{12}$ This was named after the Major General Charles Anderson, Commander of British Forces in South China from 1910 to 1913. The Line was certainly built before 1920, but was in ruins by 1926 (Weir 2012: pp.11, 17).

${ }^{13}$ Colonial Office CO129/544/14, 1933. 
Planning by the Republic of China: a Chinese Territory in a British Colony

The status of China as one of the Allied victors in the 1941-1945 war against Japan and U.S. promotion of de-colonization (Neillands 1996; Mark 2005) paved the way for an ambitious plan to reinstate Chinese administration over the Walled City. Initially, Nationalist officials from Po On County (previously San On County) under Lin Xia-zi (林俠子) sent an investigative report on the City dated 7 October 1946 to the Governor of Kwangtung (Guangdong) Province, a Mr. Luo. The report recalled the traditionally known boundaries of the City, including the stretch of the wall that went up the hill known locally as the "Ding Dong," or Lover's Rock, north of the main city wall, which was described as the "pincer of a crab". It also recollected the different residents, buildings and institutions within the fort and narrated the saga between the residents and the colonial government from the Nationalist point of view, providing good insight into the pro-China sentiments that were very much present in those days. Accounts of the demolition of the walls and houses before it was built-which was associated with the colonial government-and during the Japanese occupation were also included.

The above report was followed up by a "Draft Outline Plan for Reinstatement of Administration," dated 7 November 1946, sent in the name of Lin Xia-zi to the Governor of Canton (Guangzhou), Mr. Luo, and the Civil Affairs Bureau head, Mr. Li (李廳長). After reiterating the patriotic relevance of reinstating this small once-walled city, this plan listed steps in the transition process. (Chinese Archival Publisher 2007) Offices and institutions were proposed like a town office, tax and duty collection office, town clinic, and regional police branch office. Educational institutions from primary to secondary schools and even vocational schools were conceived. Public/private land registration and 
layout construction plans were also in the pipeline. All of these things were supposed to be steered by the Nationalist Government's guidance team.

The resumption of the civil war and defeat of the Nationalists by the Communists in 1949 meant that this Draft Outline Plan came to nothing. In fact, it was not known to City scholars until a Beijing publisher, Chinese Archival Publisher, gathered it as part of the archival materials for the City and published them in 2007.

\section{Strategic Planning in Patrick Abercrombie's Report on Hong Kong}

Britain, fighting under the leadership of Winston Churchill, had her own plan for post-war Hong Kong, but the Nationalist Chinese, with support from the U.S., considered retaking Hong Kong after Japan surrendered (Snow 1993). Sir Patrick Abercrombie, who led the writing of several important reports for post-war reconstruction in Britain from 1942 (Cherry 1996), was commissioned after the return of the colonial administration in August 1945 to draw up the first modern strategic plan for Hong Kong, which was better known as the "Abercrombie Report" (Abercrombie 1948). This plan went far beyond the reclamation proposals in Sir David J. Owen's “Future Control and Development of the Port of Hong Kong," ${ }^{14}$ which were completed in February 1941 before the Japanese invasion. Whereas the Nationalist Plan became a mere historical document, the main proposals of the Abercrombie Report, written during Abercrombie's visit to Hong Kong in 1946, were realised step by step during its immediate post-war years (Lai 1998).

In the Report's broad bush land use plan, the only plan attached to cover the whole of Hong Kong, the City was represented as a rectangular box

${ }^{14}$ See Figure 9 in Xue et al. (2012). 
with a triangle to its north - a like crab pincer, as the Chinese accounts indicated. It was zoned "Residential" like its surrounding East Kowloon setting, even though this area was rural.

In this same report's recreational plan, not a hint could be found to indicate that it would become a park near the end of the $20^{\text {th }}$ Century.

\section{Development Planning by the Colonial Government: the "Nunnery Scheme"}

The political and social situation of the City was truly a thorn in the flesh of the colonial government. The City, almost cleared of its entire population right before the war, was repopulated by squatters during the Japanese occupation and the influx of refugees into Hong Kong after the war filled all the spaces in and around the City, which no longer had its walls.

Diplomatic pressure from the Mainland - first by the KMT and then by the Chinese Communists - as well as from residents of the City, deterred the government from clearing the site for the construction of a public park.

Briefly in 1962, the Director of Public Works proposed a plan build low cost housing in the City site. Due to its merits of possibly improving public opinion over the issue better than the suggested "garden", the plan was entertained for some time and some surveys were carried out but eventually the plan did not materialize either. ${ }^{15}$

A strategic plan was devised to encircle the City and call it a "walled" City. The so-called "Nunnery Scheme"16 (see Figure 5) was approved on 1969

${ }^{15}$ Secretary for Chinese Affairs (1962), Confidential file CR6/5282/63. [HKRS 1631/2977] 28 July 1962.

${ }^{16}$ The plan in Figure 5 was based on the scheme, as plotted on a sketch drawn on 1:600 scale PWD survey plan No "C-180-NW-1," and attached to a memo signed on 
by the Governor's Committee to surround the City on three sides with developments, while the fourth side would be first dealt with prior to any action. The hope was that a well-planned, high-rise, low rent public housing estate built by the Resettlement Department would encourage City residents to surrender their land in favour of government rental housing (Lai 2016).

Figure 5: Nunnery Scheme

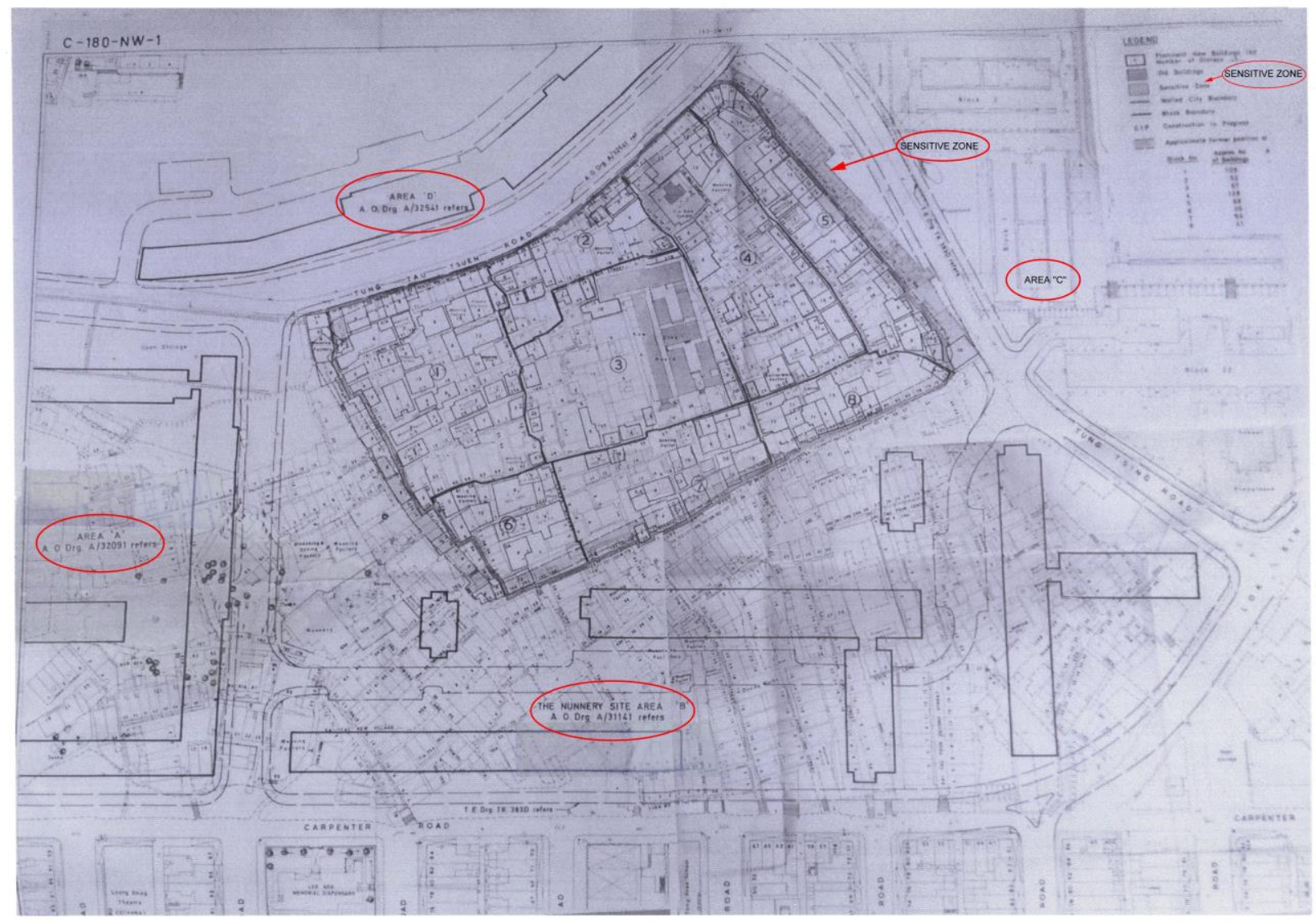

behalf of the Director of Lands and Survey (1973). By then, the UK had recognised the People's Republic of China as the legitimate Chinese Government. The name of this scheme was probably a code name. 
The three sides were of the City were divided into four areas: $A$ in the west, $B$ in the south and $C$ in the east, and $D$ in the north. The fourth side in the east was called the "sensitive zone". This zone was outside the original walls of the main fort, but deemed as part of the City in terms of building law enforcement (Lai et al. 2016). The first areas to be cleared were $A$ and $D$, which paved the way for the widening of Tung Tau Tsuen Road and government rental housing.

While the Nunnery Scheme was realised in the eastern and northern sector with the completion of Tung Tau and Mei Tung Estates, the residents of the City were not persuaded by government public housing initiatives at all and they were actually rehoused in high-rise redevelopments by developers that managed to negotiate deals for them to share in their redevelopment schemes. These private housing schemes produced an urban landscape that was much publicized under the notorious brand name, "City of Darkness". Like "Suzie Wong" popularized by Nancy Kwan's 1960 film, such branding/stereotyping distorted the fateful history of this settlement and gave a wrong impression that the government could not or did not care.

The reality was that the colonial government did not give up hope and this was reflected in its plans - both internal and statutory.

\section{Development Planning by the Colonial Government's "Administrative" Layout and Outline Development Plans (ODPS)}

The administrative Outline Development Plans (ODPs) are internal documents and only current versions can be inspected by the public. They were prepared by the Town Planning Office (TPO) before January 1990 and the Planning Department beginning on that date. There is no publicly-available index of these plans. However, Kwong's (2007) dissertation stated that a list of these plans covering Kowloon City had 
been found. Only four plans (none with any planning statement or explanatory notes) were said to be retained in the Kowloon Planning Office of Planning Department. The authors were granted permission by the Planning Department to inspect them and found the City entirely zoned Commercial/Residential (annotated C/R on the zoning map) in the earliest Wang Tau Hom and Tung Tau Outline Development Plan (LK 8/19H), which was in force from 13 July 1978 until 11 November 1982, when the City was within the Kowloon Planning Area 8. The City was surrounded by "District Open Spaces" (annotated DO). The lots under "Government, Institution and Community" (annotated G/IC) zoning at the corner of carpenter and junction road were then reserved for a primary school and multi-story car park with commercial use.

It can be said that the zoning designation for the City was compatible with the Abercrombie Report's recommendations and the tenor of the Nunnery Scheme, although $C / R$ was far more attractive than public housing as it is highly permissive, allowing the greatest flexibility to occupiers, in terms of development control.

The City was designated as part of its current Planning Area 10 in the first plan (D/K8/1D) circulated on 4 April 1986. This was also reflected in the earliest available Outline Development Plans (LK 10/24 C) dated 8 December 1966. The re-designation or transfer was first shown in the Ma Tau Kok and Kowloon City Outline Development Plans (D/K10/1B) in force from 2 October 1985 until 16 November 1992. Within this period at around 1987, all the C/R sites north of Prince Edward Road West were rezoned "Residential-Zone 1" (annotated R1 on the zoning map) except for the City and a nearby airport hotel. Afterwards, the City was rezoned to DO. Also shown in this ODP, the north eastern part of the city had an approximate airport height restrictions of $70 \mathrm{~m}$ above the principal datum and while the rest of the city was pegged at $51 \mathrm{~m}$. 
Statutory Planning by the Colonial Government's Outline Zoning Plans (OZPs)

Unlike the Nunnery Scheme or administrative town plans, all statutory plans made under the Town Planning Ordinance, which was first introduced in 1939, have always been required by law to be published in the government gazette for public scrutiny.

The earliest statutory plan prepared by the TPO under the Town Planning Ordinance that covered the City was "Wang Tau Hom \& Tung Tau Outline Zoning Plan No.LK 8/21" dated 27 April 1973. In this plan, the City was interestingly zoned for Commercial/Residential (C/R) activities - the most valuable land use - while the squatter settlement immediately adjacent to the north of Carpenter Road was zoned "residential" (R). The corner of Junction and Carpenter Roads to the west of the City was partly zoned C/R and Government/Institution and Community (see Figure 6) ${ }^{17}$. This zoning approach obviously no longer reflects any vestige of the Nunnery Scheme but for a sea of public housing.

The following statutory Outline Zoning Plan, LK 8/23, dated 26 March 1976, maintained the same zones for the City and its environs.

On 13 January 1978, LK 8/23A, "the area north of Carpenter Road was rezoned from residential to part "Government, Institution and Community" and part "Open Space" (Schedule of Amendments, I.G.). The purpose of this was to "provide a large district open space for [a] congested Kowloon City area" (Explanatory notes 4.5.3). It zoned for a seven-hectare increase in the proposed open space since LK $8 / 23$. The City remained under $\mathrm{C} / \mathrm{R}$ zoning.

${ }^{17}$ Extract from the zoning map as part of Town Planning Board plan no.LK 8/21 (27 April 1973). The $C / R$ zone was shaded and the road annotated $X$ was has never been built and disappeared after the 1987. 
Figure 6: Statutory Zoning in 1973

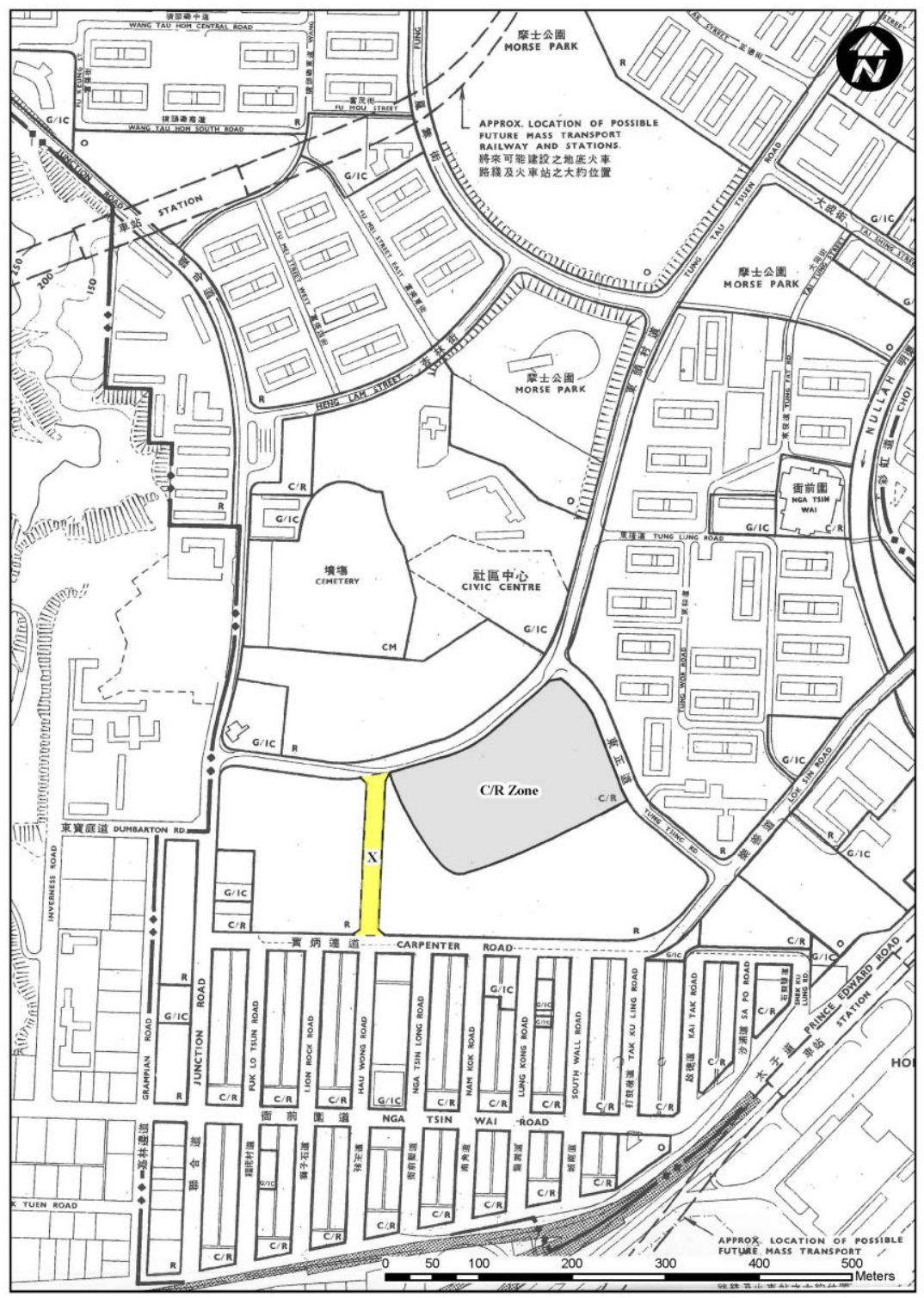

Outline Zoning Plan LK 8/23B, dated 3 October 1980, shows the space north of Carpenter's Road outside the City, which used to be divided by a small strip, as a contiguous area.

The City and its immediate environs remained unchanged in statutory Outline Zoning Plan LK 8/23D, dated 1 October 1982, the subsequent 
Outline Zoning Plan (OZP) S/K8/1, dated 30 March 1984 (gazetted after the Sino-British Agreement of 1983), and the ensuing OZP S/K8/2, dated 28 June 1985.

There was no clear indication as to why the City was designed C/R. One may speculate that this was the most politically correct zoning designation, as a $\mathrm{C} / \mathrm{R}$ zone did not make any use, except industrial, in the City to be "non-conforming". In any event, it was the most permissive zoning category available. Nor was there any attempt to zone it as a comprehensive redevelopment area. This zoning designation was made public when the relevant statutory plan was gazetted for public scrutiny and obviously no objection had ever been made.

On 2 October 1987, OZP S/K8/3 rezoned the City from C/R to open space (O). The small corner lot at Junction and Carpenter Roads also switched from $C / R$ to a simpler Residential $(R(A))$ Zone. This, together with other changes, reduced the area zoned C/R from around 13 hectares in 1973 to as little as 1.22 hectares in 1987 within the Planning Area.

A change in boundary coverage happened on 18 December 1987 (S/K8/4) when the City and its environs were "excised" from Kowloon Planning Area 8 and added to Kowloon Planning Area 10 under OZP S/K10/3 of 18 December 1987. Specifically, "the southern boundary of the planning area was amended to exclude the area around Grampian Road, Boundary Street, Prince Edward Road East, Carpenter Road, Lok Su Road, Tung Tsing Road, Tung Tau Tsuen Road, Junction Road, [and] Dumbarton Road" (S/K8/4). It is clear that this plan was intended to expedite the decision to demolish the City's buildings and turn it into a public park. It was also mentioned in the OZP's Explanatory Statement that the G/IC use of the area near Carpenter Road would be a multi-storey car park, along with some commercial uses.

The statutory zoning designation remained the same for the City and its environs in S/K10/4 of 19 May 1988 and S/K10/5 of 23 September 1988. The Carpenter Road Park can be seen taking shape in S/K10/6, dated 4 
July 1989, and S/K10/7, dated 24 December 1993, with the City still represented (wrongly) as a building complex. Only in OZP S/K10/8, dated 4 September 1998, is the Kowloon Walled City Park correctly depicted on the statutory plan.

\section{Development Planning by the Colonial Government: an Urban Park}

The latest plan for the City (Figures $\mathbf{7}^{18}$ ) was one for a public park prepared by the Architectural Services Department (Chu 1995, A Hong Kong Institute of Architects 1997, Harter 2000, Padua 2007), which was drafted soon after the colonial government announced in 1987 the decision to demolish the City and resettled all occupiers. This announcement was quickly acclaimed by China as an appropriate means to solve "a historical question". The project architect, Mr. S.K. Tse, had three goals for future park (Chu 1995), which include: to preserve the Yamen and the historical spirit of the City, to develop a Chinese garden in light of the agreement of China and Britain, and to make the park educational. The design took into account the relic canons and slabs integrated with a late Ming Dynasty (1368-1644) and early Qing Dynasty garden, (Chu 1995), specifically, "Jiangnan" (south of River Yangtze) style gardens (Padua 2007). Costing around HK\$ 59 million ${ }^{19}$, the actual garden was constructed from June 1994 to September 1995 under the Urban Council (HK Annual Report 1995). The layout of the plan as

${ }^{18}$ The base of this figure was a modern 1:1000 survey map with Road $X$ and the $C / R$ zone in the 1973 OZP plotted to denote the post war Kowloon City built up area. The informal lines in this area are design of the modern park which now stands. ${ }^{19}$ Since, 1983, US\$1 has been roughly equal to HK\$7.8 under the "link-exchange rate" system. 
implemented can be found in the Lands Department Land Index Plan record system or any government survey map for the area.

Figure 7: The boundaries of the Kowloon Walled City Park

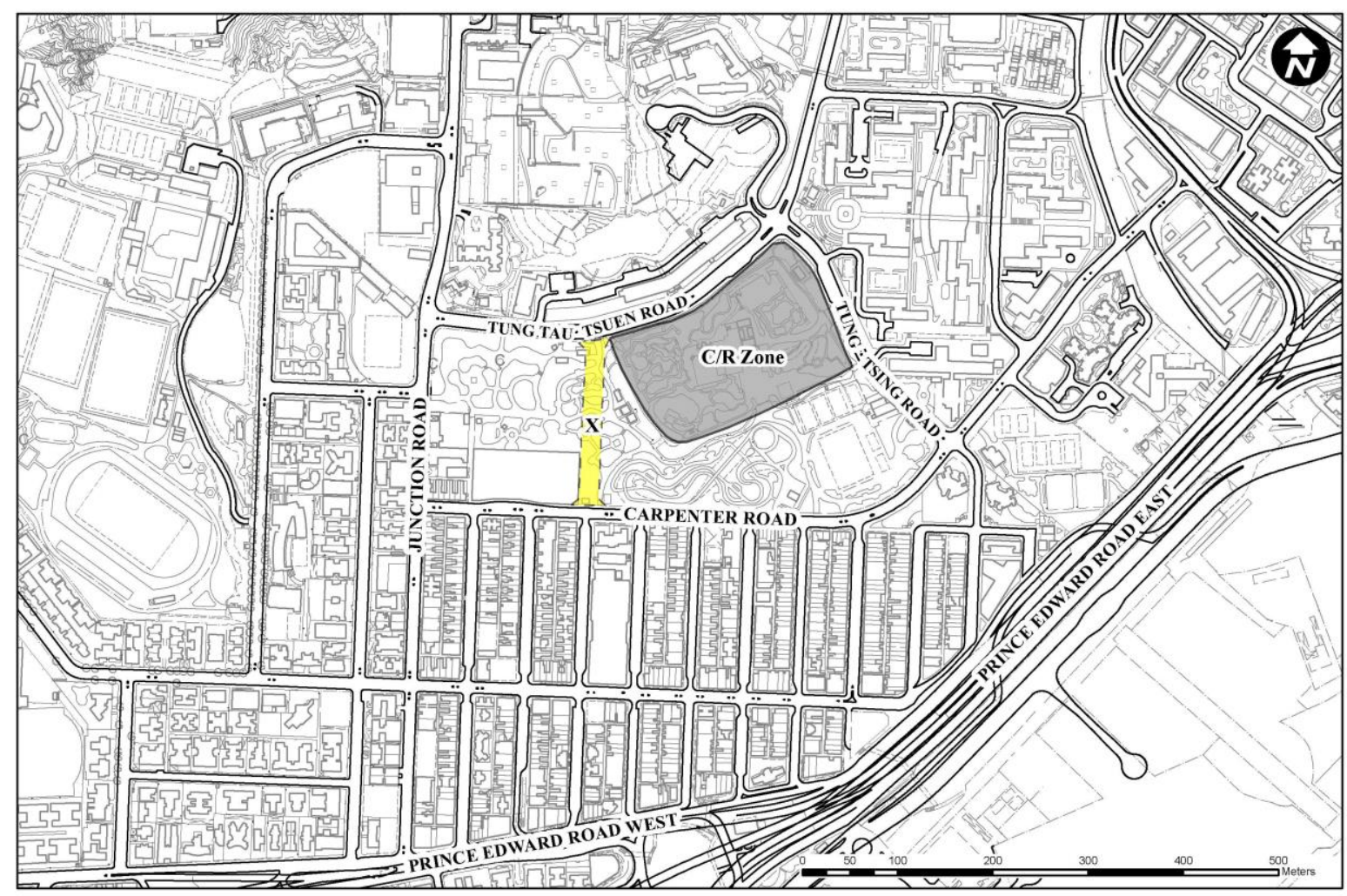

\section{Discussion and Conclusion}

This survey of the Chinese and British Hong Kong government plans for the Kowloon City revealed much and filled a void in the narratives of this "City of Darkness": the Chinese government did sporadically and the colonial government continuously kept the City as a "planned area" with carefully selected zoning designations for and around the City. For the latter, such plans were first manifested in the Nunnery Scheme and later in the internal OPDs and public OZPs. Eventually, the setting for the actual demolition of the high-rise shanty town and conversion of the City into a public park, which was a concept that was almost fulfilled before the Second World War, was eventually realised. In the process, the shape 
of the City was reduced to the original confines of the main walls of the fort.

Compared to Chinese planning, the planning by the colonial Hong Kong Government, being the de jure and de facto government of Hong Kong as a colony from 1842 till June 1997, was the most persistent and eventual prevailed: the City was reduced to a Chinese style landscaped public park at the same time the KMT cottage settlement in Rennies Mill, Junk Bay (now Tseung Kwan O) was erased from the surface of the earth. At no stage in history was the City a place unplanned.

\section{Acknowledgements}

The authors are grateful to two anonymous referees for their useful advice and suggestions for the manuscript of this paper. The mapping work for Figures 1, 2 and 5 to 7 was due to registered land surveyor Dr. Ken S.T. Ching, chartered land surveyor to whom the authors are grateful. Photo credits for Figures 3 and 4 go to the Information Service Department of the Hong Kong Special Administration Government. All faults are the authors'.

List of Plans (from north to south)

Wang Tau Hom and Tung Tau Planning Area administrative town plans: D/K8/1D (9 March 2001)

LK 8/19 H (11 November 1982)

Wang Tau Hom and Tung Tau Planning Area statutory plans prepared by the Town Planning Board:

S/K8/4 (18 December 1987)

S/K8/3 (2 October 1987)

S/K8/2 (28 June 1985)

S/K8/1 (30 March 1984)

LK 8/23D (1 October 1982)

LK 8/23B (3 October 1980) 
LK 8/23A (13 January 1978)

LK 8/23 (26 March 1976)

LK 8/21 (27 April 1973).

Ma Tau Kok Administrative Plans:

D/K10/1B (16 November 1992)

LK 10/24C (first circulated 8 December 1966).

Ma Tau Kok statutory plans prepared by the Town Planning Board:

S/K10/8 (4 September 1998)

S/K10/7 (24 December 1993)

S/K10/6 (4 Jul 1989)

S/K10/5 (23 September 1988)

S/K10/4 (19 May 1988)

S/K10/3 (18 December 1987).

Ma Tau Kok Administrative Plans: D/K10/1B (16 November 1992); LK 10/24C (first circulated 8 December 1966).

\section{List of Treaties}

"Treaty of Peace, Friendship, Commerce, Indemnity, etc., between Great Britain and China". Signed at Nanking, 29 August 1842 (Treaty of Nanking).

"Treaty of Peace, Friendship and Commerce between Great Britain and China". Signed at Tientsin 26 June 1858 (Treaty of Tientsin).

Convention of Peace and Friendship between Great Britain and China, Signed in Peking on 24 October 1860. 
"Convention between the United Kingdom and China, respecting an extension of Hong Kong Territory", with a map. Singed in Peking on 9 June 1898. (Convention of Peking)

"Joint Declaration of the Government of the United Kingdom of Great Britain and Northern Ireland and the Government of the People's Republic of China on the Question of Hong Kong". Signed in Beijing on 19 December 1984 (Sino-British Joint Declaration/Agreement) [http://www.legislation.gov.hk/blis_ind.nsf/CurEngOrd/034B10AF5D30 58DB482575EE000EDB9F?OpenDocument].

\section{List of References}

1. Abercrombie, Patrick. Hong Kong: Preliminary Planning Report, Hong Kong, Government Printer, 1948.

2. Bristow, Roger. Land Use Planning in Hong Kong: History, Policies and Procedures, Hong Kong, Oxford University Press, 1984.

3. Carney, J. "Kowloon Walled City: Life in the City of Darkness." South China Morning Post, September 4, 2013.

4. Chandler, D. Semiotics: the Basics, London; New York, Routledge, 2002.

5. Chinese Archival Publisher. Hong Kong Kowloon Walled City: Selected Archival Materials (Xiang Gang Jiu Long Cheng Zhai Dang An Shi Liao Xuan Bian), Beijing, Chinese Archival Publisher, 2007. (Chinese publication) (ISBN 978-7-80166-897-4)

6. Chu, C. "Walled City Park, Kowloon." Hong Kong Institute of Architects Journal 2 (1995): pp.86-87.

7. City District Officer (Kowloon City). "A Short Study on Multi Storey Buildings in and Around the Walled City." Confidential report dated 7.11. 1972 in Colonial Secretary (1976). "Kowloon Walled City: Implementation of Ad Hoc Committee Reports" Confidential File CR5/3371/60 Part VII. Part II. 1972 [HKRS 163-9-233 Part II] 
8. City District Officer (Kowloon City). "Hong Kong Airport (Control of Obstructions) Ordinance: Development of No.24 Tung Tau Tsuen Road, Kowloon City." Confidential memo to Secretary for Security dated 27 May 1975. 1975a [HKRS 396]

9. City District Officer (Kowloon City). "Kowloon Walled City: Occupied Buildings Exceeding Height Limits." confidential paper dated 16 October 1975. 1975b [HKRS 396]

10. Colonial Office CO129/544/14, 1933.

11. Colonial Secretary. "Kowloon Walled City: Implementation of Ad Hoc Committee Reports." Confidential File CR5/3371/60 Part VII. Part I. 1976. [HKRS 163-9-233 Part I]

12. Defence Branch, Colonial Secretariat. "Paper for the Governor Committee: Multi-storey buildings on the Periphery of the Kowloon Walled City," Confidential paper in Confidential File CR5/3371/60 Part VII. 1972. [HKRS 163-9-233 Part I]

13. Director of Lands and Survey. "Plans of Kowloon Walled City." Confidential memo dated 16 January 1973, signed by Mr. J.T. Cooper file ref. (12) in L.S.O. 5155/52B to the Defence Secretary of Hong "Kowloon Walled City: Implementation of Ad Hoc Committee Reports" Confidential File CR5/3371/60 Part VII. Part I. 1972 [HKRS 163-9-233 Part II].

14. Endacott, G.B. Government and People in Hong Kong 1841-1962: a Constitutional History, Hong Kong, Hong Kong University Press, 1964.

15. Ewise, V. "I Need Some Elbow Room." The Tiger 108, No.9, (2014), 4 April 2014.

16. Girard, G., I. Lambot, and C. Goddard. City of Darkness: Life in Kowloon Walled City, Chiddingford, Surrey, Watermark, 1999.

17. Harter, S. "Hong Kong's Dirty Little Secret Clearing the Walled City of Kowloon." Journal of Urban History 27, No.1 (2000): pp.92-113. 
18. Home, Robert K. "Colonial Town Planning in Malaysia, Singapore and Hong Kong." Planning History 11, No.1 (1989): pp.8-11.

19. Home, Robert K. Of Planting and Planning: The Making of British Colonial Histories, London, Spon, 1997.

20. Hong Kong Government. Hong Kong Annual Report 1995, Hong Kong, Government Printer 1995.

21. Hong Kong Institute of Architects [HKIA]. Annual Award, Hong Kong Architecture 3. Hong Kong, 1997.

22. Hong Kong Tourism Board. www.discovehongkong.com/eng/seedo/culture-heritage/historical-sites/chinese/kowloon-walled-citypark.jsp. 2017.

23. Jones, G. "The Kowloon City District and the Clearance of the Kowloon Walled City: Personal Recollections." Journal of Royal Asiatic Society of the Hong Kong Branch (2011): pp.257-278.

24. Kowloon Walled City Kaifong Welfare Promotion Association. Third Anniversary of the Establishment of the Kowloon Walled City Kaifong Welfare Promotion Association, Hong Kong, Kowloon Walled City Kaifong Welfare Promotion Association, 1966. (Chinese document)

25. Kwong, J.W.Y. "Planning by Contract through Development Planning: Statistical and Case Analysis." Unpublished B.Sc. (Surveying) dissertation, Department of Real Estate and Construction, University of Hong Kong, 2007.

26. Lai, Lawrence W.C. "Reflections on the Abercrombie Report 1948." Town Planning Review 70, No.1, (1999): pp.61-87.

27. Lai, Lawrence W.C. "Where to Draw the Line?' That is a Land Use Planning Question for the Land Surveyor and the Town Planner." Land Use Policy 42 (2015): pp.619-627. 
28. Lai, Lawrence W.C. "Un-forgetting Walls by Lines on Maps: a Case Study on Property Rights, Cadastral Mapping, and the Landscape of the Kowloon Walled City." Land Use Policy 57 (2016): pp.94-102.

29. Lai, Lawrence W.C., K.W. Chau, Chester K.K. Lee, and Frank T. Lorne. "The Informational Dimension of Real Estate Development: a Case of a 'Positive Non-interventionist' Application of the Coase Theorem." Land Use Policy, 41 (2014): pp.225-232.

30. Lai, L.W.C., Frank T. Lorne, K.W. Chau Ken S.T. Ching. "Informal Land Registration under Unclear Property Rights: Witnessing Contracts, Redevelopment, and Conferring Property Rights." Land Use Policy, 50 (2016): pp.229-238.

31. Mark, C.K. (2005). "Defence or Decolonisation? Britain, the United States, and the Hong Kong Question in 1957." The Journal of Imperial and Commonwealth History 33, No.1 (2005): pp.51-72.

32. Miners, Norman. "A Tale of Two Walled Cities: Kowloon and Weihaiwei." Hong Kong Law Journal 12 (1982): pp.179-156.

33. Miners, Norman. The Government and Politics of Hong Kong. Hong Kong, Oxford University Press, 1981.

34. Neillands, R. A Fighting Retreat: the British Empire 1947-97. London, Holder and Stoughton, 1996.

35. Padua, M.G. "Designing an Identity: The Synthesis of a PostTraditional Landscape Vocabulary in Hong Kong." Landscape Research 32, No.2 (2007): pp.225-240.

36. Popham, P. "The City of Darkness." Architectural Review 193, No.1161 (1993): pp.71-75.

37. Resettlement Department (1966), "Pok Oi Village Residents Fellowship Association." File RD 7/131/64. [HKRS 524-3/8] 
38. Secretary for Chinese Affairs (1962), Confidential file CR6/5282/63. [HKRS 163-1/2977]

39. Shu, Maoguan and Chongxi Wang. Xin'an Xian zhi [24 volumes] (San On County Gazetteer), Taipel, Cheng wen chu ban she, 1974 (Chinese publication) (*A rare copy of the original 1819 hand copied version can be found in the Fung Ping Shan Library of Hong Kong University.) (Chinese document)

40. Sinn, Elizabeth. "Kowloon Walled City: Its Origin and Early History," Journal of the Hong Kong Branch of the Royal Asiatic Society 27 (1987): pp.30-45.

41. Snow, Philip. The Fall of Hong Kong: Britain, China and the Japanese Occupation, London, Yale University Press, 2003.

42. Weir, Rob, "A Note of British Blockhouses in Hong Kong." Surveying and Built Environment 22, no.1 (2012): 8-18.

43. Xiao, Guojian (Siu, Kwok-kin). Jiulong cheng shi lun ji (Historical Materials on Kowloon City). Xianggang, Xian chao shu shi, 1987. (Chinese publication)

44. Xue, Charlie Q.L., Han Zou, Baihao Li, and Ka Chuen Hui, "The Shaping of Early Hong Kong: Transplantation and adaptation by the British Professions, 1841-1941." Planning Perspective, 27, No.4 (2012), 2012: pp.549-568.

45. Yau, E. New Chinese Cinemas: Forms, Identities, Politics, Cambridge: Cambridge University Press, 1994, pp.180-220. 